\title{
МОВОЗНАВСТВО
}

\section{ПРАГМАТИКА ГАСЕЛ У ПРЕСІ ПІДРАДЯНСЬКОЇ УКРАЇНИ}

\author{
КАТЕРИНА КОРОТИЧ \\ Харківський національний університет імені В. Н. Каразіна, Харків - Україна \\ korotych@ukr.net; ORCID: 0000-0002-3084-5296 \\ PRAGMATYKA HASEŁ W PRASIE UKRAINY RADZIECKIEJ \\ KATERYNA KOROTYCZ \\ Charkowski Uniwersytet Narodowy imienia Wasyla Karazina, Charków — Ukraina
}

STRESZCZENIE. Artykuł poświęcony jest funkcjonowaniu i pragmatyce haseł w ukraińskiej prasie radzieckiej. Wyróżniono najczęstsze grupy haseł ze względu na ich cel illokucyjny: konstatywne, dyrektywne, komisywne. Zaproponowano nowy rodzaj haseł slogany gloryfikacyjne, których celem było wyrażenie przychylności przedstawicieli władzy i gloryfikacja. Okazało się, że bardzo duże spektrum sloganów adresowanych do różnych grup odbiorców stanowi ważną rolę hasła jako przejawu języka władzy.

Słowa kluczowe: prasa, wpływ, hasło, adresat, konstatywy, dyrektywy, komisywy.

\section{PRAGMATICS OF SLOGANS IN THE PRESS OF SOVIET UKRAINE}

\author{
KATERYNA KOROTYCH \\ V. N. Karazin National University, Kharkiv - Ukraine
}

\begin{abstract}
The article is devoted to functioning and pragmatic load of the slogans in the Soviet Ukrainian press. The most widespread groups of slogans for their illocutive purpose are constatives, directives, commisives. The author proposed a new kind of slogans - glorivicatives, the purpose of which was the expression of favour of the authorities and glorification. It has been defined that a very large spectrum of the multidirected slogans addressed to different groups of recipients enhanced the role of the slogans as manifestations of the language of power.

Kew words: press, influence, addressee, constatives, directives, commisives.
\end{abstract}

$\mathrm{Y}$

тоталітарний період існував великий спектр засобів агітації та пропаганди, за допомогою яких формували ідеологізовану картину світу та спонукали людей до потрібних владі дій. Вивчення способів і механізмів впливу $\epsilon$ важливим теоретичним і практичним напрямом наукових досліджень і в сучасних умовах. Відповідно цю розвідку присвячено розгляду гасел як одного зі способів впливу на реципієнта в українській новомові. Лозунги розглядаємо на матеріалі періодики тоталітарної доби, оскільки, як зазначали класики ідеологічної роботи, „радянська преса виступає бойовим пропагандистом, агітатором і організатором мас”, є „могутньою зброєю ідейного впливу, політичного керівництва суспільством"1. Згідно із цим до провідних засад цієї розвідки належить

${ }^{1}$ П. С. Гуре в ич, Пропаганда в идеологической борьбе, Москва 1987, с. 131. 
постулат про те, що дискурс, зокрема політичний, можна розглядати як мовлення, що є цілеспрямованою соціальною дією².

Гасла / лозунги / слогани в українській і зарубіжній науці вже мають певний ступінь вивчення. А. Баранов, К. Бредемайер, А. Вежбицька, М. Осадчий, Н. Стасюк, I. Рудик подали їхнє визначення. Класифікації цих явищ за різними параметрами розробили А. Баранов, К. Бредемайер, М. Осадчий, К. Сопіна. На матеріалі англійської мови гасла вивчали I. Рудик, І. Сіробаба; німецької К. Бредемайер, О. Осипова, С. Шулежкова; російської - С. Анохіна, В. Кім, Г. Лассвелл, О. Осипова, О. Селіщев, С. Шулежкова, С. Якобсон, Н. Ложина та інші; словацької - С. Анохіна; української - К. Сопіна, Л. Ставицька та Н. Трач. Радянським лозунгам присвячено роботи В. Кіма, Г. Лассвелла, О. Осипової, О. Селіщева, С. Шулежкової, С. Якобсона. Проте, на жаль, функціюванню гасел в українській новомові ще не приділено належної уваги, тому ця студія покликана заповнити зазначену лакуну. Актуальність роботи посилює й потреба виявити механізми впливу на аудиторію в авторитарному й тоталітарному суспільствах, зокрема за посередництвом преси.

Мета цієї наукової розвідки - класифікувати гасла, що функціювали як засіб впливу в радянській новомові, за специфікою адресації та схарактеризувати їхнє прагматичне навантаження. Завдання - 1) сформулювати ознаки гасел; 2) класифікувати їх за типами адресатів та іллокутивною метою; 3) виявити характерні моделі побудови гасел у зазначений період. Об'єкт роботи українська новомова радянського періоду, відображена в пресі. Предмет - особливості мовного вираження, прагматичного навантаження та засобів адресації гасел як чинника впливу на особистість у тоталітарному суспільстві. Матеріалом дослідження стали лозунги, дібрані з текстів української преси комуністичного спрямування за 1919-1945 pр.

У тлумачних словниках ${ }^{3}$ гасло в політичному значенні містить семи 'стислість', ‘звернення', ‘ідея', ‘вимога', ‘завдання', ‘політика'. Дефініції лозунга в політологічних словниках і посібниках ${ }^{4}$ репрезентують також семи 'чіткість', 'пропаганда' та 'політичний ідеал'. Гасло як форма вербального повідомлення передається від адресанта, яким виступає особа чи група осіб, наділених владою (партія, уряд, політичний діяч), до адресата: або всього населення, або його окремих верств чи категорій осіб. Зважаючи на ці ознаки гасел, визначаємо їх як висловлені в лаконічній влучній формі провідні ідеї часу, політичні завдання, звернені керівництвом до всього населення певної держави або його окремих груп. Згідно із цим ми добирали гасла за наявністю означених сем, причому деякі $з$ них могли бути імпліцитними, але легко відновлювалися з контексту. Крім того, деякі фрази та вислови в текстах преси відразу було марковано як гасла („Не повинно бути жодної робітниці неписьменної'5 - здійснити це гасло є практичне завдання сьогоднішнього дня [Ком. Укр., 1929, № 6, с. 12-13]; Ці запаси [нафти — К. К.] дають нам змогу розгорнути нафтовидобуток та-

${ }^{2}$ Н. Д. А рутюн ов а, Дискурс, [в:] Лингвистический энииклопедический словарь, гл. ред. В. Н. Ярце в а, Москва 1990, с. 136.

${ }^{3}$ Словник украӥнської мови, в 11 томах, гол. ред. І. К. Білодід, Київ 1970, т. 1, с. 614; Словник украӥнської мови, ... 1971, т. 2, с. 39; Словник украӥнської мови, ... 1972, т. 3, с. 147.

${ }^{4}$ С. Д. Гелей, С. М. Рутар, Лозунг, [в:] Їх же, Політологія, гол. ред. Ю. Левен е ц ь Львів 2001, с. 319; Г. Даш у тін, Гасло політичне, [в:] Електронний ресурс: http://subject. com.ua/political/dict/306.html (27.04.2018); О. Пан фі л о в, Гасло політичне, [в:] Політична енциклопедія, гол. ред. Ю. Л е в е н ец , Київ 2011, с. 129.

${ }^{5}$ Назви джерел, цитати та приклади наводимо відповідно до правопису оригіналу. 
кими розмірами, щзо Америка мусить поступитися периим місцем перед СРСР. Наша техніка в цій галузі стоїть на такому щзаблі, щзо вже можна конкретно говорити про здійснення гасла, „наздогнати й випередити" ПАСШ щудо нафттовидобутку в найкоротші строки [АДМ, 1932, № 10, с. 44]).

Слово гасло в політичній термінології має такі синоніми, як заклик, відозва, лозунг та ін. Розгляньмо види гасел, що функціонували в українській пресі радянської доби.

Із радянської преси 1919-1945 рр. вилучені гасла за типами адресатів розподіляємо на декілька категорій: 1) за географічною та національною належністю: гасла, звернені до (а) певних верств населення всього світу (Пролетарі свіmy, всі, як один, ставайте на оборону Радянського Союзу! [АДМ, 1932, № 1112, с. 53]); (б) гасла, звернені до всього населення Радянського Союзу (Хай живе Союз Сочіялістичних Радянських Республік! [Рад. Сел., 1925, № 13-14, с. 1]); (в) груп народів (Брати слов'яни! Всі сили на розгром німецьких загарбників - смертельних ворогів слов'янства! Хай живе бойовий союз слов 'янських народів, щуо борються за знищення гітлерівської тиранії! [А., 1944, № 9, с. 2]); (г) окремих націй (Привіт польському народові, щзо бореться проти німецькофашистських загарбників! Патріоти Польщі!! Всіма силами допомагайте вашим визволителям - Червоній Армії і Польському військові швидше розгромити ненависних німецьких окупантів! Хай живуть доблесні солдати і офрічери Польського війська! [А., 1944, № 9, с. 1]); 2) за класовими та професійними ознаками - гасла, звернені до окремих верств населення: (а) селян (Посуху бий колгоспом [Рад. Сел., 1924, № 16-17, с. 1]); (б) робітників, серед них шахтарів, металургів, будівельників, залізничників і представників інших професій (За 100\% явку на работу, за реалізацію 6-ти вказівок тов. Сталіна, за дотермінове закінчення Дніпровського будівництва [Б., 1932, № 19-20, с. 34]); (в) військових (Воӥни Червоної Армії! Невтомно вдосконалюйте свою бойову майстерність, повністю використовуйте нашу прекрасну бойову техніку, бийте ворожі війська до повного їх розгрому! [А., 1944, № 9, с. 2]); (г) зрідка інтелігенції (Радянська інтелігенція! Інженери і техніки, агрономи, вчителі, лікарі, працівники науки, мистецтва і літератури! Службовці радянських підприємств і установ! Допомагайте робітникам і колгоспникам у дальшому піднесенні нашого народного господарства! Посувайте вперед радянську науку, техніку і культуру! Хай живе радянська інтелігенція! [А., 1944, № 9, с. 4]); 3) за релігійними / атеїстичними ознаками - гасла, звернені до атеїстів, висловлюючись мовою того часу, “безвірників” (...Геть хрест - символ рабства й пригноблення, геть релігію - знаряддя закріпачення трудящчи! [ЧК, 1930, № 4, с. 22]; ... гасло, щзо „боротьба проти релігї є боротьба за сочіялізм” [АДС, 1932, № 36, c. 22]); 4) за гендерними ознаками, оскільки за тодішніми директивами жінок із метою збільшення трудових ресурсів посилено намагалися залучати до активного соціального та політичного життя й професійної діяльності - гасла, звернені до (а) жінок (Селянки Украӥни, поліпшуйте сільське господарство, заводьте кращзі культури та машинну обробку землі. Поширюйте колективні об' єднання [Ком., 1926, № 2, с. 44]); (б) чоловіків (Танкісти Червоної Армії! Трошіть і невідступно переслідуйте ворога! [А., 1944, № 9, с. 2]); 5) за віковими ознакамигасла, звернені до (а) дітей, зокрема школярів (Діти, відкривайте очі вашим батькам та дорослим на релігійний дурман! [Б., 1929, № 7, с. 70]); (б) молоді (Молодь на штиики [ідеться про опанування військової справи - К. К.] [МБ, 1937, № 8, с. 85]); (в) людей середнього та літнього віку (Громадянине! До сіл 
і до міст вдерся гад ненажерний — фашист. Пригадай партизанський хист Бий у гриву його i в хвіст! [CX, 1941, № 155, с. 3]), хоча в останньому прикладі, очевидно, що адресат повинен був мати військові навички й, можливо, партизанське минуле, тому це гасло поєднує кілька ознак адресата; 6) за належністю до ідеологічних організацій - гасла, звернені до (а) піонерів (Юні піонери! Mu мусимо завоювати пролетарських дітей [ЧК, 1929, № 17-18, с. 3]); (б) комсомольців (Збирайте ж свої молоді сили в похід на зеленого змія! Перемога буде за вами! [МБ, 1925, № 12, с. 10]); (в) членів Комуністичної партії (Кожен комуніст повинен бути активним атітатором за партію [АДС, 1932, № 31, с. 20]).

За часів радянсько-німецької війни адресати хоч і були охоплені ідеєю боротьби, але мали дещо відмінні завдання. Відповідно, виокремлюємо ще один поділ адресатів - за місцем перебування: (а) ті, хто перебуває в (а) Червоній Армії (Радянські льотчики - соколи нашої Батьківщини! Нещадно знищуйте ворога на землі, в повітрі і на морі! Хай живуть радянські льотчики! [А., 1944, № 9, с. 2]); (б) ті, хто перебуває в тилу (Працівники військового тилу! Автомобілісти і иляховики Червоної Армії! Своєчасно доставляйте Червоній Армії бойову техніку, боєприпаси, спорядження і продовольство! Хай живуть пращівники військового тилу! [А., 1944, № 9, с. 2-3]); (в) ті, хто перебуває в зоні бойових дій (Танкісти Червоної Армї! Трощіть і невідступно переслідуйте ворога! Умілим і сміливим маневром проривайтесь у тили противника, відрізуйте шляхи відходу ворожим військам, знищуйте німецьких загарбників! Хай живуть радянські танкісти! [А., 1944, № 9, с. 2]); (г) ті, хто перебуває на окупованій території або скоро опиниться там (I тут - фронт! I колгосп - фортеия! [CX, 1941, № 157, с. 3]; Брати українці! Всі на боротьбу проти німещьких загарбників! [Біл., 1943, № 4, с. 1]); (г) ті, хто перебуває в територіях, з яких відступили німецькі війська (Трудящі районів, визволених від німещької окупащії! Швидше відбудовуйте міста і села, промисловість, транспорт, зв'язок, сільське господарство і культурно-побутові заклади, зруйновані гітлерівськими розбійниками! 3 кожним днем збільшуйте допомогу своїй визволительиі - Червоній Армії! [А., 1944, № 9, с. 4]).

Засоби адресації могли бути як наявними в структурі гасел, експліцитними, так й імпліцитними. Уживання звертань у гаслах було логічним і закономірним, адже вони виконували важливі завдання: 1) передусім, як зазначають С. Якобсон та Г. Лассвелл, „посилювали вплив на аудиторію”, що, на нашу думку, зумовлене диференційним підходом творців лозунгів до різних категорій людей, що відображалося у звертаннях, і природною властивістю людини реагувати на слова, звернені до неї (нехай навіть і дистанційно та в складі групи інших осіб); 2) здійснювали оцінно-характеристичну функцію (Сини України, славні воїни Червоної Армії! Ще міиніше бийте ворога! [А., 1944, № 9, с. 9]) та, за нашими спостереженнями, функцію маркування належності до СРСР. Такими маркерами у звертаннях радянської доби були прикметник радянський та інші радянізми на позначення особи: комсомолець, піонер, ударник, стахановець, колгоспник (напр., Радянські жінки! Оволодівайте виробничими спеціальностями, підвищуйте продуктивність праці, вивчайте справу протиповітряної і протихімічної оборони, санітарну справу, зв'язок [А., 1944, № 9, с. 4]; Комуністи і комсомольці! Будьте в перших рядах борців проти німецько-фашистських загарбників! [А., 1944, № 9, с. 4]); 3) мали закличну функцію, що зумовлено природою гасла.

${ }^{6}$ С. Якобсон, Г. Д. Лассвелл, Первомайские лозунги в Советской России (19181943), [в:] „Политическая лингвистика”, гл. ред. А. П. Чудино в, Екатеринбург 2007, № 1, c. 124 . 
За нашими спостереженнями, власне звертання до адресатів було вербалізоване не завжди, інколи їх не називали, очевидно, для збереження лаконізму гасла та через успішну відновлюваність адресації з контексту.

Як видно з наведених класифікацій, лозунги мали розгалужене коло адресатів, а радянські ідеологи максимально їх диференціювали й охоплювали якнайбільше груп населення, надаючи кожній з них свої завдання. Найбільшу кількість гасел відстежуємо у 20-30-х рр. ХХ ст., що пов'язано з екстралінгвальними причинами (припиненням визвольних змагань і зміцненням позицій радянського ладу, залученням до виробничого процесу та суспільно-політичних організацій більшої кількості населення, зокрема жінок і молоді, упровадженням ідеології майже в усі сфери життя), натомість певне звуження реєстру гасел спостерігаємо у зв'язку з воєнними обставинами в 1941-1943 pp.

Використовуючи класифікації мовленнєвих актів (МА) Дж. Остіна та Дж. Сьорля, у дискурсі радянської преси 1919-1945 рр. виділяємо кілька найпоширеніших груп гасел за їхньою іллокутивною метою, тобто змістом конкретного типу іллокуції: 1) констативні, тобто такі, що співвідносяться з констативами (лат. constat - містити в собі, стояти стійко) - мовленнєвими актами, що позначають стан речей, відображають факти об'єктивної дійсності (чи такої, яку нею вважають у певному соціумі $)^{8}$; 2) директивні, тобто такі, що співвідносяться з директивами - мовленнєвими актами, іллокутивна мета яких - змусити адресата зробити щось у майбутньому'; 3) комісивні, тобто такі, що співвідносяться 3 комісивами (лат. commissum - доручати) - мовленнєвими актами, метою яких $є$ прийняття адресантом зобов'язання зробити / не зробити що-небудь ${ }^{10}$; 4) експресивні, тобто такі, що співвідносяться з експресивами (лат. expressio - вираження) - мовленнєвими актами, мета яких окреслити певний психологічний стан мовця (почуття вдячності, радості, співчуття тощо) ${ }^{11}$, причому ознакою цього типу МА, за Дж. Сьорлем, $є$ істинність, адже мовець, здійснюючи такий тип МА, не намагається пристосувати ані реальність до слів, ані слова до реальності ${ }^{12}$, чого ми часто не спостерігаємо за радянської доби, де відбувалося маніпулювання і словами, і фактами; 5) бехабітивні, тобто такі, що співвідносяться з бехабітивами (англ. behave - поводитися, habit - звичка) різновидом експресивів, формулами соціальної ввічливості ${ }^{13}$.

В усіх цих МА, крім комісивів, соціальний статус адресанта вищий, ніж в адресата, тому вони мають значний ступінь прескриптивності, найвищий у директивів. Зауважимо, що навіть у комісивах, граматично побудованих від першої особи, “за кадром" залишаються представники влади, які спонукають брати на себе ці обіцянки робітників, селян, журналістів та ін. і виголошувати їх “з уст народу". Навіть у констативах, хоч їм, звичайно, і властива дескриптивність, спостерігаємо імпліцитну приписовість, оскільки ці мовленнєві акти описують модельовану згідно з владними приписами картину світу. Прикметно, що ми не зафіксували в українській пресі аналізованого періоду квеситив-

${ }^{7}$ Дж. Р. Серль, Классификация иллокутивных актов, [в:] „Новое в зарубежной лингвистике”, общ. ред. Б.Ю.Гор одецкого, Москва 1986, вып. XVII, с. 172.

${ }^{8}$ Ф. С. Бац е в и ч, Основи комунікативної лінгвістики, Київ 2004, с. 329; Дж. Л. О с т и н, Слово как действие, [в:] „Новое в зарубежной лингвистике”, .., с. 22-129.

${ }^{9}$ Ф. С. Бацевич, зазнач. джер., с. 322; Дж. Р. Серль, указ. источ., с. 182.

10 Ф. С. Бацевич, зазнач. джер., с. 328; Дж. Л. Остин, указ. источ., с. 124; Дж. Р. Серль. указ. источ., с. 182.

${ }^{11}$ Ф. С. Бацев ич, зазнач. джер., с. 323; Дж. Р. Серль, указ. источ., с. 183.

${ }^{12}$ Дж. Р. Серль, указ. источ., с. 183.

${ }^{13}$ Дж. Л. Остин, указ. источ., с. 126. 
них МА. Очевидно, це пов'язано з тотальною директивністю гасел, у яких не допускалися навіть риторичні питання.

Наведемо приклади різнотипних гасел, що функціювали в пресі 19191945 pp.

У констативних лозунгах описано певний стан речей, нав'язуваний ідеологічними приписами, та озвучено ключові ідеї часу (Міліиія - відданий вартовий революиійної законности [РМ: одноднівка, 1929, с. 4]; Ленінська партія наша партія, Радянська влада - наша влада [АДС, 1933, № 5-6, с. 57]). Ці гасла у 20-30-х рр. ХХ ст. могли бути засобом ідентифікації так званих “своїх", пізніше ставали засобом ритуалізації, підтвердження своєї лояльності до влади.

Директивні гасла містили спонукання адресата до здійснення певних дій, що виражалося формами наказового способу (Бийте скажених фашистів! [К., 1941, № 174, с. 3]), інфінітивами (Четверту весну [першої п’ятирічки - К. К.] зустрінути по-більшовиизькому [Рад. Акт., 1933, № 1, с. 1]) або й прийменниково-іменниковими чи прислівниково-іменниковими конструкціями без дієслів, але з типовою інтенцією вимоги (Робітниці - до профспілок! [Ком. Укр., 1922, № 11, с. 4]; Більше вугілля, металю, машин. За економічну незалежність СРСР! [АДМ, 1932, № 11-12, с. 49]).

Своєрідними різновидами директивних гасел були фрази з ключовими словами геть і смерть, що спонукали до вилучення з радянської дійсності або й знищення об'єктів опису (Геть другорічників із школи [ГЧК, 1930, № 1 (27), с. 1]; Геть братовбивчу громадянську війну! [ЛР, 1932, № 3-4, с. 136]; Смерть німеиььким окупантам! [ЗРУ, 1942, № 14, с. 1]).

Під впливом комісивних гасел мовець брав на себе зобов'язання виконати певні дії або дотримуватися визначеної поведінки (Виховаємо молодих безвірників [Б., 1929, № 21, с. 58]). Ці гасла звичайно містять дієслова у формі 1-ої особи множини майбутнього часу переважно доконаного виду й справляють враження, що висловлюють думку певних верств або представників населення країни (Зробимо иеей рік останнім роком труднощзів [АДМ, 1933, № 19, с. 1]; Не допустимо, щоб агресивні країни знову створили загрозу мирному життю народів! [ПУ, 1945, № 8, с. 4]). Гасла комісивного типу стали особливо популярними з уведенням п’ятирічних планів (з 1928 р.).

Експресивний і бехабітивний різновиди гасел можна об'єднати в один, що за тоталітарних часів охоплював вияви ритуального славослів'я та прихильності згідно з тодішньою ідеологією. Пропонуємо як робочу назву слово тлорифiкатив (від лат. glorificatio - уславлення). Як було зазначено вище, такі гасла могли не відображати дійсності й бути істинними, а радше виконували функцію ритуальних мовленнєвих актів, що було типовим для радянського дискурсу (див. про ритуалізацію, напр., у Б. Потятиника ${ }^{14}$ ). До тлорифікативних відносимо лозунги, побудовані за схемою: сталий предикат в описовій формі наказового способу хай живе + суб'єкт - важливий символ радянської дійсності (Хай живе всесвітня Сочіяльна Револющія! [ЧП, 1919, № 3, с. 1]; Хай живе Перше Травня! [АДМ, 1932, № 11-12, с. 8]). Інколи ці гасла поширювалися розгорнутими прикладками (Хай живе Жовтнева револючія - світоч всесвітньої революції, щио перемагає як на фронті політичному, так $і$ на господарчому. Хай живе Комуністична Партія - вождь робітництва й селянства усього свіmy! [Рад. Сел., 1924, № 14-15, с. 3]). Через значні потрясіння, викликані Другою світовою війною, у 40-х рр. ХХ ст. гасла такого типу стали вільні-

\footnotetext{
${ }^{14}$ Б. По т я т и и к, Медіa: ключі до розуміння, Львів 2004, с. 426-427.
} 
шими за структурою й почали відображати абсолютні цінності (Хай живе мічний мир між народами! [ПУ, 1945, № 8, с. 4]). У таких лозунгах водночас намагалися відобразити наявність соціалістичних чи загальнолюдських цінностей і утвердити їх. Крім того, наявний і елемент експресії, пафосу, якого намагалися надати окличною інтонацією, що на письмі позначали відповідним розділовим знаком, описовою формою хай живе та значною кількістю позитивно оцінних слів та ідеологем.

Другим структурним різновидом глорифікативних лозунгів $є$ фрази, побудовані за схемою: слово привіт + додаток, на місці якого простий чи складений номен, що позначає особу або осіб, які на час створення гасла мали прихильність партії та уряду, що й передає певний вислів (Привіт народам Свропи, шео борються проти гітлерівського імперіалізму! [Агіт., 1944, № 9, с. 2]; Ударникам і ударнииям, передовим бориям великої армії будівників сочіялізму - більшовицький привіт! [Рад. Акт., 1933, № 4, с. 5]). Слово привіт могло мати означення-ідеологеми на зразок більшовицький, комуністичний, палкий, а структурні компоненти інколи зазнавали інверсії, коли треба було наголосити на об'єкті впливу.

Гасла, що побутували в радянській пресі, могли бути простими - у цьому разі вони співвідносилися лише з одним типом мовленнєвих актів, а також складними, що поєднували у структурі кілька видів МА, посилюючи перлокутивний ефект. Напр., у складному лозунгу Радянські юнаки і дівчата! (1) Caмовіддано трудіться на допомогу фронтові, оволодівайте технікою виробництва, військовою справою, показуйте зразки трудової дисципліни! (2) Хай живе радянська молодь! [Агіт., 1944, № 9, с. 4] поєднано два різноспрямовані МА: директив (1) і глорифікатив (2); а лозунги (1) Привіт франиузькому народові, що разом з союзними арміями завершує визволення Франиії від німеиького іга! (2) Бойовий привіт доблесним льотчикам франиузької авіаційної частини „Нормандія”, що спільно з радянськими льотчиками громить німецькофашистських варварів! [Агіт., 1944, № 9, с. 1] складаються з двох односпрямованих глорифікативних гасел. Складені лозунги зазвичай містили дві-три відозви, але могли складатись і з більшої кількості гасел ((1) Bсі до дружньої роботи! (2) Забезпечимо явку 100\% вибориів на збори! (3) Оберімо кращих товаришів і товаришок у нові ради! (4) За проводом партії Леніна - до нових перемог [Ком. Укр., 1929, № 6, с. 1]). Такі гасла частіше були приурочені до важливих подій ідеологічного характеру: свят, виборів, воєнних перемог, - коли представникам влади було важливо дати директиви, ушанувати й окреслити ідеологічно “правильний” стан речей.

Залежно від змін чи сталості політики партії щодо певних питань гасла могли бути постійними, статичними, зумовленими ідеологічними константами (Думка про об'єднання робітників усіх країв для боротьби з всесвітнім капіталом була висловлена великими вчителями пролетаріяту Марксом та Енгельсом ще 1847 року в „Комуністичному маніфесті”, що закінчувався бойовим закликом: „Пролетарі всіх краӥн, єднайтеся!” [Рад. Сел., 1924, № 13, с. 4]), і тимчасовими, динамічними, пов'язаними з певними подіями (Забезпечимо перемогу над фашистською поганню [К., 1941, № 152, с. 3]).

Як бачимо, надзвичайно великий спектр різноаспектних гасел, звернених до різних груп населення, забезпечував значну роль гасла як вияву мови влади. Такі гасла виконували низку функцій (закличну, диференціювальну, оціннохарактеристичну, функцію маркування належності до СРСР), комплексно впли- 
ваючи на адресатів. Радянські гасла співвідносилися з різними типами мовленнєвих актів: констативами, директивами, комісивами, частково з експресивами та бехабітивами. Два останні види МА пропонуємо об'єднувати в один різновид лозунгів, що кваліфікуються як глорифікативні: їхнє призначення - виразити прихильність представників влади та уславлення. Виділяємо прості (однокомпонентні) та складні гасла, що містять кілька лозунгів, які можуть співвідноситися з одним чи кількома типами МА, інтенсифікуючи вплив на аудиторію.

Перспективу дослідження вбачаємо в необхідності вивчення джерел походження гасел, їхнього вербального оформлення та виявлення механізмів їхнього впливу на реципієнта.

\section{Список джерел і прийнятих скорочень}

Агіт. - „Агітатор”

АДМ - „Агітатор для міста”

АДС - „Агітатор для села”

Б. - „Безвірник”

Біл. — „Більшовик”

ГЧК — „Газета «Червоних квітів»”

ЗРУ — „За Радянську Україну”

К. - „Комуніст”

Ком. - „Комунар”

Ком. Укр. - „Комунарка України”
ЛР — „Літопис революції”

МБ - „Молодий більшовик”

ПУ — „Партробітник України”

РМ - „Радянський міліціонер”

Рад. Акт. - „Радянський Активіст”

Рад. Сел. - „Радянський Селянин”

CX - „Соціалістична Харківщина”

ЧК — „Червоні квіти”

ЧП — „Червоний прапор”

\section{Список використаної літератури}

Арутюнова Н. Д., Дискурс, [в:] Лингвистический энииклопедический словарь, гл. ред. В. Н. Ярцева, Москва 1990.

Бацевич Ф. С., Основи комунікативної лінгвістики, Київ 2004.

Гелей С. Д., Рутар С. М., Лозунг, [в:] Їх же, Політологія, гол. ред. Ю. Левенець, Львів 2001. Гуревич П. С., Пропаганда в идеологической борьбе, Москва 1987.

Дашутін Г., Гасло політичне, [в:] Електронний ресурс: http://subject.com.ua/political/ $\operatorname{dict/306.html~(27.04.2018).~}$

Остин Дж. Л., Слово как действие, [в:] „Новое в зарубежной лингвистике”, общ. ред. Б. Ю. Городецкого, Москва 1986, вып. XVII, с. 22-129.

Панфілов О., Гасло політичне, [в:] Політична енциклопедія, гол. ред. Ю. Левенець, Київ 2011.

Потятиник Б., Медіа: ключі до розуміння, Львів 2004.

Серль Дж. Р., Классификация иллокутивныхх актов, [в:] „Новое в зарубежной лингвистике", общ. ред. Б. Ю. Городецкого, Москва 1986, вып. XVII, с. 172-183.

Словник української мови, в 11 томах, гол. ред. І. К. Білодід, Київ 1970-1980.

Якобсон С., Лассвелл Г. Д., Первомайские лозунги в Советской России (1918-1943), [в:] „Политическая лингвистика”, гл. ред. А. П. Чудинов, Екатеринбург 2007, № 1, c. $123-142$.

\section{Spysok vykorystanoi literatury [References]}

Arutiunova N. D., Diskurs, [v:] Lingvisticheskij e`ncyklopedicheskij slovar [Linguistic Encyclopedic Dictionary], hl. red. V. N. Yarceva, Moskva 1990.

Batsevych F. S., Osnovy komunikatyvnoi linhvistyky [Fundamentals of Communicativce Linguistics], Kyiv 2004. 
Helei S. D., Rutar S. M., Lozunh, [v:] Yikh zhe, Politolohiia [Moto], hol. red. Yu. Levenets, Lviv 2001.

Gurevich P. S., Propaganda v ideologicheskoj borbe [Propoganda in Ideological Struggle], Moskva 1987.

Dashutin H., Haslo politychne [Political Moto], [v:] Elektronnyi resurs: http://subject.com. ua/political/dict/306.html (27.04.2018).

Ostin Dzh. L., Slovo kak dejstvie [Word as Action], [v:] „Novoe v zarubezhnoj lingvistike”, obsh. red. B. Yu. Gorodeczkogo, Moskva 1986, vyp. XVII, s. 22-129.

Panfilov O., Haslo politychne [Political Moto], [v:] Politychna entsyklopediia, hol. red. Yu. Levenets, Kyiv 2011.

Potiatynyk B., Media: kliuchi do rozuminnia [Media: Keys to Understanding], Lviv 2004.

Syorl' Dzh. R., Klassifikaciya illokutivnyh aktov [Classification of Illocutive Acts], [v:] „Novoe v zarubezhnoj lingvistike”, obsh. red. B. Yu. Gorodeczkogo, Moskva 1986, vyp. XVII, s. 172-183.

Slovnyk ukrainskoi movy [The Ukrainian Language Dictionary], v 11 tomakh, hol. red. I. K. Bilodid, Kyiv 1970-1980..

Yakobson S., Lassvell G. D., Pervomajskie lozungi v Sovetskoj Rossii (1918-1943) [May, 1 Motos in Soviet Russia], [v:] „Politicheskaya lingvistika”, gl. red. A. P. Chudinov, Ekaterinburg 2007, № 1, s. 123-142. 